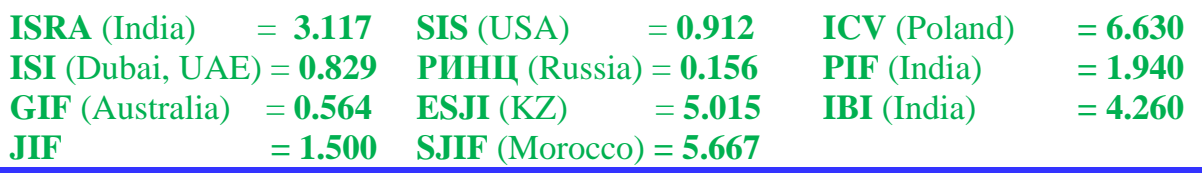

QR - Issue

SOI: $\underline{1.1 / \text { TAS }}$ DOI: $\underline{10.15863 / \text { TAS }}$

International Scientific Journal Theoretical \& Applied Science

p-ISSN: 2308-4944 (print) e-ISSN: 2409-0085 (online)

Year: $2018 \quad$ Issue: 12 Volume: 68

Published: $29.12 .2018 \quad$ http://T-Science.org

SECTION 29. Literature. Folklore. Translation Studies.
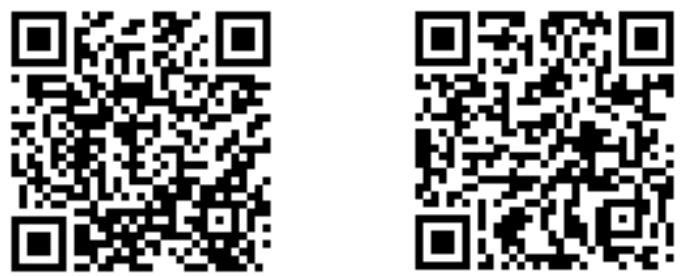

T.F. Verdieva Scholar

Nizami Ganjavi Center of Ganja Department Azerbaijan National Academy of Sciences, Ganja, Azerbaijan tarana.verdiyeva-83@mail.ru

\title{
ABOUT HISTORICAL-CULTURAL INVESTIGATION OF LITERARY HERITAGE OF GANJA
}

Abstract: Article deals with the research of mentions the remarkable palace poet Gatran Tabrizi's life in Ganja period, reflecting the socio-political and cultural environment this city in his destinies. The study found that Ganja was the capital of the XI century as a socio-political and culturally high-rise city. Although various sources have been proven to be true in the historical sources, the names of those who have an important role in the social and scientific development of the city have not been named. Only the names of the rulers in power at that time were mentioned. In this research, information is given about a number of personalities selected in their scientific and cultural life in ancient Ganja. Using the poems of Gatran Tabrizi, we have added these names to some of the names of city intellectuals. The fact that the great scientists who have lived in Ganja in the XI century, emphasizes the importance of the city. This research work is important in terms of promoting the ancient history of city.

Key words: Gatran Tabrizi, Ganja, the state of Shaddadids, Tabriz, XI century.

Language: English

Citation: Verdieva, T. F. (2018). About historical-cultural investigation of literary heritage of Ganja. ISJ Theoretical \& Applied Science, 12 (68), 287-289.

Soi: http://s-o-i.org/1.1/TAS-12-68-42 Doi: crossef https://dx.doi.org/10.15863/TAS.2018.12.68.42

\section{Introduction}

The lyrical poems of the creative spirit and superior intelligence of Gatran Tabrizi brought him to the tops, fame, and then transformed his Gatran identity into a research object of literary scholars and scholars after him. At any given time, the influence of certain creatures on human beings is crucial to having such a creativity, intelligence, and fame. There is no doubt that in the first place there is a person's knowledge, knowledge and beautiful speech.

However, the most important factor that creates conditions for evolution is the environment within the human body. As the mighty artist of Gatran Tabrizi, his shining way of life and the environment have a great impact.

The feudal relations developed well since the Shaddadis was founded in the late Middle Ages. The capital of the state Ganja turned into a large trade and cultural center of the Caucasus. There were beautiful palaces, magnificent mosques, madrasas, caravanserais, hamams, morgues, and other beautiful cultural monuments of the era. The trade route to the western regions of Azerbaijan, Georgia and the
Black Sea coast passed through Ganja. Ganja craftsmen: beautiful silk fabrics, carpets, sculptures, and palaces of Seljuk sultans, were also brought to world markets [4, 295].

The first arrival of Gatran Tabrizi to Ganja also coincided with the period of the city's development and development in many areas. According to researchers, the first arrival of the poet to Ganja falls to the reign of Aran ruler Abulhasan Ali Lashgari (1033-1050) [3, 48].

At that time the ruler of Ganja gathered very brave, brave warriors and intelligent and knowledgeable scientists around him. This made Ganja stop at one of the highest levels in the sociopolitical and cultural life of the same period. All these statements were reflected in the Divan of Gatran Tabriz, along with sources reflecting the history of the XI century Ganja.

In XI century, many scientists, educated scientists and other intellectuals lived in Ganja. Gatran Tabrizi meant "science and culture army". The poet's use of "science and culture" is not accidental. Because there is also a culture of science.

Given the development of the capital city of 


\begin{tabular}{|c|c|c|c|c|c|c|}
\hline \multirow{4}{*}{ Impact Factor: } & ISRA (India) & $=3.117$ & SIS (USA) & $=0.912$ & ICV (Poland) & $=6.630$ \\
\hline & ISI (Dubai, UAI & $=0.829$ & РИНЦ (Russia) & $=0.156$ & PIF (India) & $=1.940$ \\
\hline & GIF (Australia) & $=0.564$ & ESJI (KZ) & $=5.015$ & IBI (India) & $=4.260$ \\
\hline & JIF & $=1.500$ & SJIF (Morocco) & $=5.667$ & & \\
\hline
\end{tabular}

Ganja in the eleventh century, it is easy to understand that Gatran Tabrizi also tends to Ganja, and that the poet's poetry is a special place in Divan. Gatran Tabrizi A number of poems included in the Divan are addressed to friends and colleagues living in Ganja, as well as writing memoirs in honor of the rulers of Ganja.

True, these poems do not mention Ganja, but it is a historical fact that these personalities live in this city. If you take into account that a city is known for its culture, science and those who embody it, that is, in Tabrizi poems, he has glorified Ganja.

In addition to the socio-political and cultural environments of Ganja, artists living there also had a great influence on Gatran's creativity. A number of people who lived in Ganja in of the Gatran Tabriz in medieval mosque and mediated by Gatran Tabriz in Ganja, wrote and wrote there.

This mastery plays an important role in investigating the life of Gatran in Ganja. During the reign of Abullazr Abul-Hasan Ali Lashkari, mentioned in the early days of Mesnawî, Arran was the superiors $[1 ; 414]$.

\section{Materials and Methods}

Ganja, one of the oldest cities of the East with a centuries-old history, connecting the north-eastern slopes of the Lesser Caucasus mountains with the expanses of the Kur-Araz lowland, is located in a picturesque corner of Azerbaijan with a temperate climate, fertile lands rich in water resources.

Historically, Ganja has always had a favorable geopolitical location and played an important role in the cultural and economic life of Azerbaijan. This city was built on the Great Silk Road, which connects Asia with Europe. Thus, Ganja was the spiritual bridge between different civilizations.

One of the famous persons of this city is Nizami ganjavi. Meanwhile it is hardly accidental that we mentioned this contentious couplet relating to the place of birth of Nizami. Throughout history, along with those seeking to claim ownership of many Azerbaijani values and territories, there have also been people attempting to appropriate the genius descendants of Azerbaijan, and such attempts are happening to this day.

During Nizami's era, two languages - Arabic and Persian - dominated science and literature in the near and Middle East. All scientific works were written in Arabic, while poets from a diverse range of nationalities in Central Asia, the Caucasus, Iran and India crafted their literary heritage in a single language - Persian.

With clear command and knowledge of information in the most varied fields of science reflected in his works, Nizami demonstrates that he is a highly-educated person. His earliest known verses indicate his high poetical techniques. And this is evidence of Nizami's engagement in poetry not as an amateur but as a genuine professional, someone who perfectly mastered the theoretical basis of this art from the very beginning.

Nizami's name was Ilyas, However, certain sources claim that his name was Ahmad (for example, the source entitled "Khulasat al-afkar" notes his name as Ahmad ibn Yusif Muayyad). Nizami is a nickname of the poet. His pseudonym was Nizam ad-din. In the medieval Moslem East there was a tradition of indicating kunya, the son's name, along with the name of famous persons.

The kunya of Nizami is Mohammad. In his various hemistiches the poet speaks to his son Mohammad through admonishing him. From his first poem to his last, Nizami repeatedly brings the name of Ganja to his hemistiches. And one of these couplets is an excellent riposte to those trying forcibly to extricate Nizami from Ganja and artificially connect him to other places. Seemingly responding to all these a few centuries in advance, he states his permanent belonging to Ganja:

My secrets-my words coming from my spirit are made obvious,

Though he is taken to Boukhara, his origin from Ganja.

Certain sources inform about Nizami's brother Givami Mutarrizi. The literary relics written by Givami Mutarrizi that we possess today attest to his high skills in the genre of qasida-masnavi, as well as hiss overall poetic talent and savy poetic technique.

But during the XI century in Ganja lived Gatran Tabrizi, in very few cases, also carried out diplomatic missions among these states. Even the details of the ongoing conflict and warfare were also highlighted. That is why creativity, Gatran poetry, and Gatran's intelligence have attracted not only linguists, orientalists and poets but also scholars and historians. Azerbaijani scientist and historian Seyid Ahmed Katheravi wrote some of the three volumes of his work "Shahriyarani-gömnam" on the basis of the Gatran Tabrizi Divan.

In the foreword written by Gulamhusein Begdeli, a classic Azerbaijani literature researcher wrote in the foreword to the Divan: "Cutaway, referring to the work of this outstanding poet of the XI century, has determined the lives of several individuals. The historical personalities he lived during that period, in his work, point to the events that took place". G. Begdeli states that from the works of Gatran Tabrizi, in the XI century, many issues related to the history of Azerbaijan can be found that most of them are not known to the science world by Seyid Ahmed Kassawi's "Shahriyaranigömnam" [1, 11]. 


\begin{tabular}{|c|c|c|c|c|c|c|}
\hline \multirow{4}{*}{ Impact Factor: } & ISRA (India) & $=3.117$ & SIS (USA) & $=0.912$ & ICV (Poland) & $=6.630$ \\
\hline & ISI (Dubai, UAI & $=0.829$ & РИНЦ (Russia) & $=0.156$ & PIF (India) & $=1.940$ \\
\hline & GIF (Australia) & $=0.564$ & ESJI (KZ) & $=5.015$ & IBI (India) & $=4.260$ \\
\hline & JIF & $=1.500$ & SJIF (Morocco) & $=5.667$ & & \\
\hline
\end{tabular}

\section{Conclusion}

In the twelfth century, art and literature, architecture and poetry became the denial of the feudal ideology of the century, leading to socioeconomic development. Humanism gained a special role in the Renaissance $[3 ; 89]$.

These developments, which are manifest in various fields, especially in literature, have, of course, not happened at once. There must have been some reasons to push it forward. These reasons have already begun to arise in the XI century as a result of the activities of artists, scholars and writers in Ganja.

At that time, artists like Gatran Tabrizi, who lived in Ganja, had a positive impact on the social and cultural life of the city and in the future they formed the basis of personality formation such as Nizami Ganjavi, Mahsati Ganjavi.
We have added these names to the Ganja intellectuals in the article, using the poems of Gatran Tabrizi. The fact that the great scientists who have lived in Ganja in the 11th century, emphasizes the importance of the city.

The study found, that Ganja was the capital of the XI century as a socio-political and culturally high-rise city. Although various sources have been proven to be true in the historical sources, the names of those who have an important role in the social and scientific development of the city have not been named. Only the names of the rulers in power at that time were mentioned. In this research, information is given about a number of personalities selected in their scientific and cultural life in ancient Ganja. There has been no such investigation in Ganja concerning the XI century.

\section{References:}

1. Təbrizi, Qətran (1967). Divan. Bak1: Azərbaycan SSR Elmlər Akademiyası nəşriyyatı.

2. (1960). Azarbaycan adabiyyatı tarixi. I cild. Bakı: Azərbaycan SSR Elmlər Akademiyası nəşriyyatı.

3. Səfərli, Ә., \& Yusifli, X. (1982). Qədim va orta asrlar Azarbaycan adabiyyatı. Bakı: Maarif nəşriyyatı.

4. Azərbaycan tarixi (2007). I cild. In: bZ.M.Bünyadovun və Y.B.Yusifovun (Eds.) Bakı: Çıraq nəşriyyatı.

5. Şrifli, M. (1978). IX asrin II yarısı - XI asrlarda Azarbaycan feodal dövlatlari. Bak1: Elm.

6. Rəcəbli, Qəzənfər (2013). Azərbaycan tarixi. Oçerklar. Bakı: Elm və təhsil.

7. Gəncəvi, Nizami (2012). Iskandərnamə. Gəncə: GDU nəşriyyatı.
8. İbrahimov, Sənan (2015). Divan adabiyyatının poetikası. Bakı: Bakı Universiteti nəşriyyatı. 127.

9. (n.d.). Min yaşlı Qətran. Professor Qara Namazov. Retrieved 2018, from www.Ekinchi.az

10. Hasanov, E. L. (2016). About comparative research of poems "Treasury of Mysteries" and "Iskandername" on the basis of manuscript sources as the multiculturalism samples. International Journal of Environmental and Science Education, 11(16), 9136-9143.

11. Abdullayeva, N. (n.d.). Dünyanın on zəngin kitabxanalarından biri haqqinda. Retrieved 2018, from www.Palitranews.az

12. (n.d.). Gəncə, Qapıları. Retrieved 2018, from www.az.wikipedia.orq

13. Ohməd, Vüqar, (2007). Әdəbiyyatşünaslıq. Dərslik. Bakı: Müəllim nəşriyyatı. 